\title{
Local Dimension of Celebrations. Holidays as a Tool in Creating State Symbolic Space at Local Level - the Case Study of Poland
}

\begin{abstract}
State celebrations, anniversaries of important historical events and their observance are one of the main channels of communication between ruling elite and society that shape the state symbolic space. In addition to establishing memorial sites, erecting monuments, founding institutions focused on remembrance, they are the most important way to create a narrative of the state's past. In Poland - regardless of time and political system - special attention was paid to creating a calendar of holidays and anniversaries, and the manner they were celebrated. These festivities were and are still considered to be fundamental tools used in Polish politics of history, both at state-wide and local level. Their importance in the regions can - depending on how the local elites exercise their powers - vary from much larger in relation to the central state level to entirely negligible. The aim of this study is to present mechanisms and tools used by local authorities in building an appropriate historical narrative using just those tools.
\end{abstract}

\section{Keywords:}

holidays, politics of history, symbolic space, symbolic culture, local authorities

1 Faculty of Political Sciences and International Studies, Nicolaus Copernicus University in Toruń, Poland, kkacka@umk.pl. 


\section{INTRODUCTION}

All struggle for power is de facto struggle for influence - this applies to all domains of state functioning, including the system of politics of history together with state symbolic space, which constitutes an important factor in shaping national identity. In this respect, struggle for power means primarily desire to obtain control over interpretation of history, the process of shaping the memory of citizens and methods of recreating the past in the present (Wolff-Powęska, 2007). Understanding the nature and importance of these elements in modeling social attitudes is the key to success in the field of politics of history. It is no surprise then that historical arguments throughout history have been, regardless of geography, consistently and with high efficiency used in the "political game" played by the ruling elites, often contributing to ideological victory of one of the parties (Kosthorst, 1985). Certainly, one can cite just as many examples of such triumphs as of political disasters caused by disregard for or inexpert use of historical arguments, and neglect for the role played by the past in the present. There is no doubt that history - or rather the way we remember it - is a major tool in the hands of the authorities, and the ability to use it properly directly affects the effectiveness of their actions (Zaborski, 2011).

State symbolic space is one of the basic channels of communication between government and society, hence its proper management and organization is essential. There is no doubt that the key element of this space is the narrative about the past and attempt to use it for "current” purposes (Piechowiak-Lamparska, 2014). An excellent tool to achieve this goal is the calendar of state holidays and an integrated list of historical events considered most important from the perspective of the given state and nation. This allows to produce within a particular society a habit of remembering the past, which is a specific condition for belonging to a particular community (Cassirer, 1971). Organization of a calendar of celebrations, holidays and anniversaries is one of the simplest, yet most effective ways to build a sense of community in a state, and at the same time define a catalog of values that the ruling elite wants to implement among the citizens (Szpociński, 1983).

Studies of symbolic space require methodological approach combining many aspects (Kącka, 2015b). Analysis of any anniversary celebration should cover two dimensions: its central state level and local level versions, as well as the manner and elements of celebration itself. The basic methods used include first of all content analysis, popular in cultural studies, and anthropological approach as concerns study of processes of ritualization of public holidays. In practice, this means combining approaches from different research areas in the process of 
observing and analyzing the aforementioned phenomena - after all, public holidays, anniversaries of significant historical events and the ways they are celebrated are a communication activity where multiple cultural codes come into play, and where a wide range of diverse factors and indicators - often difficult to measure - must be taken into account. The key issue for all studies in this field is analysis of the communication process itself, and the context of this act along the sender content - medium - receiver continuum. In the case of holidays and important anniversaries, this translates into the following interdependencies: ruling elite - narrative of the past - celebration - society. Public holidays and anniversaries thus become a tool used to achieve a predefined result by giving them particular meanings through their repeated "use" by the authorities. Specific conditions of the communication act occurring during such a celebration also encourage reflection on the relationship between sender and receiver of the message. According to Michael Walzer (2006) - especially in the conditions of liberal democracy - the ruling (sender) treat the public (receiver) as members and contributors, co-creators of the community, not just consumers of a political rite. Analysis of national calendars of holidays and analysis of how they are celebrated in different countries, however, lead to suggesting a correction to Walzer's view. Without questioning the strength of democratic attitudes and ideas in various societies, it should be explicitly stated that they are insufficient to truly sustain the thesis of an equal partnership between authorities and society, especially as we move from the sphere of declarations to real political practice. A good example here are the election campaigns, in which introducing an appropriate historical narrative, participation in and skillful shaping of state holiday celebrations can prove highly useful and bring measurable effects in the form of seizure of power. Analysis of electoral tools and mechanisms and methods of their use clearly puts into question the optimistic assumptions of Michael Walzer.

\section{STATE HOLIDAYS IN POLAND}

History and dynamics of changes in the Polish calendar of holidays in the 20th century clearly confirm that regardless of the prevailing political system it was used as a specific element of a "cultural game", which on the one hand carries out specific functions related to the very existence of a state - such as socialization, integration, legitimation, ethical function and finally valorization - and on the other hand is a tool in political struggle used to achieve individual goals. The ruling elite thus take on the role of creators of politics of history and social engi- 
neers, determining the shape of historical consciousness of a given community. They create own vision of the past, articulated in the priority national narratives, communicated via and manifested in the specific calendar of state holidays and anniversaries, as well as the ritualistic manner of their celebration. This could be used to, for example, give legitimacy to a new political order or re-legitimize the old one (Wolff-Powęska, 2011).

Political changes in Poland after 1989 brought about significant changes in the calendar of holidays in Poland, and partially also in the way they are celebrated. This is a direct consequence of the desire for complete ideological disassociation from the former socialist regime, and for ensuring effectiveness of the transition process also on the consciousness level. Given the scope of difficulties the new authorities faced, reforming the calendar of celebrations seemed an easy task with the added bonus of bringing immediate effect. It also facilitated the process of rebuilding a sense of national identity and reconstruction of national community. It should be noted, however, that this was not a one-off event, but a lengthy process, and the catalog of holidays is still - although with less intensity - evolving. As concerns public holidays, the first change was the restoration in 1989 of the National Independence Day, celebrated on November 11 (Act of 15 February 1989). The National Day of May 3rd (commemorating the first Polish constitution) was reactivated as well (Act of 6 April 1990 a), while the feast of the Assumption of the Blessed Virgin Mary, celebrated on August 15, has been declared also the Day of the Polish Army (Act of 30 July 1992) and given the status of a day off from work (Act of 17 May 1989). The catalog of state celebrations that are also non-working days should be effectively expanded to include also the New Year and all Sundays, as well as the following church feasts: Epiphany - restored in 2010, the first and second day of Easter, the first day of Pentecost, Corpus Christi, Assumption, All Saints' Day, the first and second day of Christmas (Act of 24 September 2010; Act of 16 December 2010; Proclamation, 2014). The Polish calendar of holidays contains also three other national holidays that, although they remain normal working days, are of a particular nature. The first is the Day of Solidarity and Freedom (Act of 27 July 2005), established in 2005, the second - the National Day of Remembrance of the Warsaw Uprising (Act of 9 October 2009) declared in 2009 and finally, announced in 2011, the Doomed Soldiers Memorial Day (Act of 3 February 2011). Simultaneously, the authorities launched an organized effort at removing from the public space all elements clearly linked to the period of the Polish People's Republic, including such holidays as the National Day of Poland's Revival (July 22) (Act of 6 April 1990 b) and the National Day of Victory and Liberty (in this latter case, only in 2015 [Act of 24 April 2015] the Polish Parlia- 
ment passed a law giving the celebration a new name: National Victory Day, and moving the celebration from May 9 to May 8; it is now a normal working day) ${ }^{2}$.

Celebrations of all state holidays - regardless of whether they have the status of a day off from work or not - have both a central, state-wide, and local aspect. Such events are for the most part held simultaneously at central and regional levels. The former take place mostly in the capital, Warsaw, and are attended by the most important representatives of the state government: President, Prime Minister, Marshals of the Lower (Sejm) and Upper (Senat) Parliament Chambers, etc. They have several common elements, which include: paying homage to symbols of state, singing of national anthem, speeches, performances by (usually) military bands and the Honor Guard of the Polish Army. Locally, state holidays are celebrated usually in regional capitals, but also in smaller towns - albeit on a considerably more modest scale; the form and scale of these celebrations depend directly on the representatives of local governments. It is worth noting that these events are to a large extent a local-level copy of ceremonies held at state level in the capital. Only in extremely rare cases state ceremonies held in the regions incorporate specific local customs (if such exist).

\section{LOCAL DIMENSION OF HOLIDAYS AND ANNIVERSARIES IN POLAND}

Making use of public holidays as a tool to build historical narrative at state-level is relatively easy. Answering the question concerning the use of this mechanism at local level is not so simple, however. Locally, the process depends mainly on two factors: state administrative division and division of powers in the area of politics of remembrance between central state administration and local governments. Polish law gives local authorities a high degree of freedom in this domain (at all three of the local government levels: municipal, district and province - voivodship). And although main responsibility for shaping the state symbolic space remains in the hands of the central government, local government officials have considerable influence over historical consciousness of inhabitants of their respective regions or localities (Kącka, 2014). This stems directly from the power to enact local laws and give approvals - for example, erecting a monument (Kącka, 2013) requires approval from a relevant local decision-making body (e.g., the city council). And although local authorities cannot influence the calendar of state holidays, they can

2 For more information on history of and changes in the public holiday calendar, see: Kącka (2015a). 
- with a great deal of freedom - awaken memory of events and historical figures related to a particular region (a similar mechanism). Historical anniversaries in this case are much more sensitive to local influences. State holidays - as mentioned before - have a pre-defined agenda and form of their celebration, and thus giving them a more local character can be difficult - especially as the receiver of this particular message, the society, expects a specific and reproducible scenario of the related ceremonies. Thus creating instead a local calendar of anniversaries of important events in parallel to the state-wide calendar of such events may be for representatives of local governments an opportunity not only to shape the desired attitudes among citizens, but - what is of great importance to politicians - for appropriate self-presentation. A much more complicated issue in this context, however, is to analyze the level of skill and effectiveness shown in the use of the competences making the above influence possible by the local authorities. The outcomes are vastly different depending on location and local government level represented.

Societal expectations are high in this regard. Importance of holidays, anniversaries and related celebrations has been gradually but consistently growing since 1989. It is mainly the result of these events being freed from overbearing influence of local governments and effective mobilization and involvement of local civil society in their stead. Also participation of the public in the celebrations and local festivities has been steadily growing. Public holidays and anniversary celebrations thus take on an integrating role, and serve to activate local communities. Furthermore, they can also become a factor in local PR activity, attracting tourists to a city, town or village (Kurczewski, 2003; Przecławski, 2001). A generation that does not remember the obligation for citizens to actively participate in May 1 parades in the communist times, which caused aversion to this kind of "patriotic" activity among youth of that time, is now entering adult life. Hence today, for many young people - though it is of course a generalization - participation in marches celebrating state independence, in historical reconstructions and other ceremonies is in fact a privilege and a symbol of national pride ${ }^{3}$.

Polish traditions and history provide ample opportunities for making use of the most important figures and historical events in the framework of politics of history. It is well understood by representatives of local authorities and administration, who rightly see in this a chance to build regional narratives of the past and shape right attitudes, for example of the so-called local patriotism. In practice, however, it turns out that the centuries-long state history is only to a negligible degree used

3 These attitudes and their motivations are not uniform, and require further in-depth study. 
in local politics of memory, and the regional narratives of the past only rarely refer to events dating back further than the 20th century. In this regard, one can observe a high degree of consistency at local and central level. In fact, beyond celebration of anniversary of the May 3rd Constitution, local narratives currently reach also to events from the January Uprising (1863), and - to a lesser degree - the November Uprising (1830). It is difficult, however, to consider this as deliberate building of a historical narrative, as celebrations of anniversaries of these events are usually limited to laying flowers on the graves of the insurgents or monuments dedicated to them, and stem more from a sense of obligation of the local authorities than desire to build political capital on this basis.

Among earlier events the anniversaries of which are still celebrated in Poland one should mention above all the Battle of Grunwald (July 15, 1410). The memory of this event is boosted by the largest historical reconstruction taking place in Poland every year in the fields of the Grunwald village. The reconstruction attracts crowds of lovers of medieval history, who reconstruct the course of this Polish victory, which - mainly thanks to the novel by Henryk Sienkiewicz, "The Knights of the Cross" [Krzyżacy], and its eponymous film adaptation by Aleksander Ford has gained a legendary status. Also in this case, however, it is difficult to treat the reconstruction event as contributing to shaping of the state symbolic space (Schenk, 2009). Although there is undeniably some symbolic significance to the event, not only thanks to the historical medieval battle, nowadays it is mainly a great tourist attraction and commercial success. The role of local authorities is therefore limited only to preparation of the event as concerns administrative requirements (licenses, permissions, etc.), ensuring safety of participants from medical and sanitary point of view, as well as protecting the public order. The case of the Battle of Grunwald shows how difficult and complicated it is to build a narrative of the past which could serve the ruling elite in attaining current political objectives and shaping desired social attitudes. This example of an event whose date is known to all Poles proves that to effectively make use of the past in the present, one more element is needed.

This necessary element are emotions. In the opinion of Ernst Cassirer (1971), they play the most important role in the perception of the past by man. Arousing emotions in the receiver of a message is therefore a key condition for creating a successful narrative about the past. The above-cited example of the Battle of Grunwald does not meet this requirement. Even the best performance will remain only a tourist attraction if it does not wake the appropriate emotions, and this is precisely the case of this reconstruction. Much more effective use of this anniversary was made in the days of the Polish People's Republic, when it was used 
to perpetuate the Polish-German antagonisms, which especially in the period immediately after the war was not difficult. Contemporary Poles have, in a sense, inherited the mechanism identifying the Germans with the Teutonic Order/Knights of the Cross established at that time (Kąkolewski, 2015). To this day, the analogy is used pretty often by fans at sporting events involving confrontation of the Polish and German athletes (Ociepka, 2001). With time, it disappeared from the political sphere, and its possible revival in this context would undoubtedly lead to an international scandal.

Emotional factor can be much easier put to use in the case of events chronologically closer to the present times, especially if witnesses of the given events still live, and their testimony can be used to significantly strengthen the narrative. For this very reason, politics of history implemented in Poland attempt to activate memory of events from the not-so-far past. Thus state holidays and anniversaries mainly refer to events of the 20th century: regaining independence by Poland, Second World War and liberation of Polish lands from the German occupation, as well as anti-regime protests from the period of the Polish People's Republic, which had culminated in Poland's eventual transition to a democratic system.

One of the most important narratives present in Poland since 1989 is the memory of independence and traditions of the Second Polish Republic. Homage given to this period of the state's past is particularly evident in the symbolic space, mainly in the form of monuments, names of streets, squares and schools named after political leaders of the 1920s, such as Józef Piłsudski and Roman Dmowski. Is also reflected in the calendar of public holidays and anniversaries. The most important is of course the National Independence Day, feted throughout the country - this event, however, is connected to a series of locally celebrated anniversaries, linked to the tradition of "return to the motherland", or gradual re-incorporation of individual regions into boundaries of the Polish Republic. This "return" was caused by a variety of events: signed treaties, armed struggle, peaceful takeover, insurrections and plebiscites, mainly taking place in the period 1918-1922. All in all, these events provide an excellent opportunity to strengthen local patriotism and cultivate regional customs and traditions. Still, nowadays, without thinking to resign entirely from celebration of these events, some community leaders - primarily in Silesia - call for removal of the "return to the motherland" narrative. It is de facto a call for coming back to historical truth, as some of these lands had only - as a result of clashing political forces and conflicting interests - belonged to Poland very briefly before, sometimes as far back as a few centuries earlier (Urbańczyk, 2008). So in fact one cannot talk here about a return, but rather about joining only. This state of affairs is mainly the consequence of actions in the domain of 
politics of history of the communist propaganda apparatus, which in this manner was building a narrative about inherent Polishness of these lands. Even use of the term "Regained Lands" (sometimes "Recovered Lands") during communist time was perpetuating this vision of the past in people's minds. Of course, this problem does not apply only to Silesia - it is, however, the region where the call for rejection of this narrative is the loudest. This call is met with accusations that it is inspired by grassroots initiatives calling for the autonomy of Silesia, while the leaders are under suspicion of building their own political platform under the guise of slogans of return to historical truth.

A leading region that efficiently and effectively activates the memory and tradition of regained independence is Greater Poland - Wielkopolska. This is particularly evident during celebration of anniversaries of the Wielkopolska Uprising, where the Society of Remembrance of the Wielkopolska Uprising 1918/1919 can boast particular achievements. The institution was formed in 1989, and since 2004 enjoys the status of a public benefit organization. Its mission is to maintain the memory of the Uprising events through educational and promotional activities. The anniversary observance begins in Poznań every year on December 26, with a symbolic welcome for Ignacy Jan Paderewski, returning from exile. The pianist and politician stopped in Poznań on his way to Warsaw and delivered a rousing patriotic speech. Wielkopolska Uprising is surrounded by a particular cult in the entire region, reflected in a local map of sites of memory dedicated to this event. Since the turn of the 1990s, authorities of the Wielkopolska region have been trying to spread the memory of the Uprising throughout the country, highlighting its eventual victory - the only one in the history of Polish insurrections. In fact, the insurgents in just a few weeks gained control of the entire province, with the exception of its northern and south-eastern parts. The truce in Trier ending the Uprising on February 16, 1919 extended the principles of the Compiègne truce to cover also the insurgent-controlled lands in Wielkopolska (Czubiński, 1988). So far, however, this tradition still has a more local character, and the attempts to raise its awareness to a nationwide level failed. Though the previously Poznań-specific culinary tradition of St. Martin's Day croissants has successfully spread in Poland, and the croissants are now sold throughout the country around November 11 . This failure should also be considered as proof of dominance of customs associated with state-level celebrations in the capital over those spearheaded by regional governments.

Parallel to independence narratives, also the memory of the Second World War is activated repeatedly. Of course, next to holidays of nationwide character: National Victory Day, the Warsaw Uprising Memorial Day, and the increasingly 
celebrated Doomed Soldiers Memorial Day, every region cultivates the memory of the most important local events of that time. In Gdańsk, on September 1 on the Westerplatte peninsula the symbolic day of the beginning of World War II on the Polish territory is remembered. The heroic defense of the Military Transit Depot functioning there testifies to Polish resistance against German aggression (Kubisz, 2008). The place of the "Battle of Westerplatte" was - on September 1, 2003 entered onto the list of Polish history memorial sites (Regulation, 2003). These celebrations have a very solemn character, with participation of representatives of the highest state authorities, members of the diplomatic corps and the church hierarchy, what puts the ceremony on par with other state holidays celebrated normally in the capital.

Celebrations linked to the events of liberation of individual Polish regions from the German occupation, which took place at different times, starting with the Red Army entering the Polish territory in January 1944, and ending in May 1945, are of a much more local character. Over this short period, the Polish lands were completely overrun by the Soviet army, which remained there until 1993. In practice this meant Poland transitioned from German occupation directly into the emergent socialist system. Nowadays, in a growing number of locations the narrative describing these events as "liberation" of Poland is dispensed with as increasingly controversial. More and more often, representatives of local authorities refrain from organizing these celebrations, limiting themselves only to celebrating the National Day of Victory. The narrative of the WWII shows also a significant shift of emphasis towards honoring the memory of the so-called cursed or doomed soldiers and the anti-communist guerrillas in Poland. This is the result of a change in interpretation of significance of the "threshold" year 1945, which now symbolizes the end of the war, but not the end of occupation of Poland.

A special place in the Polish symbolic space is occupied by a series of anniversaries associated with memory of the period of Polish People's Republic - mainly major protests for freedom and rights of citizens and workers, the history of which has for years been distorted or erased from the consciousness of Poles by the socialist propaganda. The memory of these events, although initially celebrated locally, with time has taken on an increasingly nationwide character. It turns out that the ruling elite rarely forgo a chance for raising to a state level the memory of events whose significance is consistent with the political message they want to communicate. It is thus extremely difficult to find, at local level, anniversaries and public holidays associated with pro-freedom protests which, firstly, are not of interest to the ruling politicians in Warsaw as a possible component of the narrative they are building, and secondly, can still be effectively used in regional politics 
of history. An example of a local event anniversary which took on a national dimension is the anniversary of Poznań June 1956. The first ever general strike in the history of the Polish People's Republic began then in the plant now known as Henryk Cegielski Metal Works, which in the years 1949-1956 still bore the name of Joseph Stalin. The social protests have been quickly and violently suppressed by the militia and the army, while the event, named by the propaganda "the June incident”, was completely downplayed and ignored. Some Poles learned of the strikes in Poznań from foreign media. The first celebration of the anniversary of Poznań June was held in Warsaw in 1976. The anniversary Mass in the church of St. Jack was attended by: Jacek Kuroń, Antoni Macierewicz, Seweryn Blumsztajn, Ludwik Dorn, Jan Olszewski, Jan Józef Lipski, Władysław Siła-Nowicki, and Wojciech Ziembiński. The most important symbol of these events is the monument towering over the Mickiewicz square in Poznań, whose unveiling ceremony attracted more than a hundred thousand participants (Grzelczak, 2016). Of greatest significance and pomp were the celebrations of the 50th anniversary of Poznań June in 2006, attended by five presidents of the former people's republic: Lech Kaczyński for Poland, Horst Köhler from Germany, Vaclav Klaus for the Czech Republic, Ivan Gašparovič from Slovakia, and László Sólyom from Hungary. The memory of these events is particularly venerated in Poznań, and the anniversary celebrations are among the most important annual events in the city - but their profile has certainly been raised to a much more than local celebration. This is evidenced by the Resolution of the Sejm of the Republic of Poland of June 21, 2006, establishing June 28 as the National Day of Remembrance of Poznań June 1956 Events.

The narrative of March 1968, when strikes and student demonstrations broke out in protest against banning of the theatrical drama "Dziady" directed by Kazimierz Dejmek at the National Theatre in Warsaw led to a serious political crisis in Poland, cannot be compared with the scale of celebrations of Poznań June (Eisler, 2006; Madajczyk, 2012). Anniversaries of these events, of a typically local nature, are feted in several cities in Poland where major strikes and protests took place, including Warsaw, Gdańsk, Cracow, Poznań, Łódź, and Radom. The same applies to celebrations of anniversary of June 1976, when a wave of strikes caused by introduction by the government of Piotr Jaroszewicz of drastic price increases for necessities broke out in Poland (Sasanka, 2006). An analogous situation can be observed in the case of commemorating the strikes in Lublin and Świdnik of July 1980, where once again the direct cause was the rise in food prices (Dąbrowski, 2000). These events are remembered on a purely local level, and usually the celebrations are initiated by people who experienced them directly. Nowadays, the 
narrative concerning strikes organized in protest against price increases seems for the young generation of Poles somewhat exotic and out of touch with the current reality. It is thus difficult to arouse emotions focused on these events in persons directly unaffected by them or their outcomes - thus local authorities make little use of them in their efforts to shape the local symbolic space. Commemorating these events is also made more difficult by lack of specific (i.e., day of the month) dates when the anniversary celebrations could and should be held.

A completely different narrative is associated with the strikes on the Coast in 1980, which were the consequence of those initiated in Świdnik and Lublin. Particularly important from the point of view of anti-regime tradition in Poland is the anniversary of the signing of the so-called August Agreements, celebrated annually on August 31 (Raina, Szostak, 2003). To commemorate this event, the Day of Solidarity and Freedom was established, celebrated for the first time in 2005. This date marks the moment when the Coastal festivities lost their strictly local dimension; although the main festivities still take place in Gdańsk, the celebrations are nationwide. For the last several years, due to a conflict dividing the heirs of the former "Solidarity" movement, the anniversary causes many controversies, distorting the memory of those events in public consciousness. A similar phenomenon can also be observed in the case of narrative of the year of freedom - 1989. Ideological disputes around such events as the negotiations in Magdalenka (1988/1989), the Round Table Agreement and June elections do not allow for proper reception by the public of often contradictory messages, communicated by the conflicted parties (Dudek, 2003). This results in rejection of these events in the consciousness of Poles as important for the history of the state. Prolonged conflict interferes also with the possibility of creating a proper ritual, which is how celebrations of all holidays and anniversaries can be viewed.

A similar - so far unsolvable - dispute continues around the interpretation of events associated with the anniversary of introduction on December 13, 1981 of martial law in Poland. Perhaps the relative temporal proximity of these events and their freshness in people's memory make a reasoned interpretation - the conclusions of which are for the historians and scholars of this period already clear and unambiguous - impossible. In this context, it is worth mentioning an important event linked to the introduction of martial law in Poland - namely the pacification on December 16, 1981 of protests in the "Wujek" mine in Katowice, when miners opposing the decision of the authorities were massacred by the militia. As a result of the pacification, 9 miners were killed and 24 were injured. The anniversary of these events in Silesia has been celebrated consistently since 1982, even in times when honoring the fallen miners was prohibited by law and was associated with 
serious legal consequences. These celebrations for many years were of a local character, and the regional authorities - especially after 1989 - have taken those events and their remembrance under particular care. At the end of 2015, the Regional Assembly of the Silesia Province adopted a resolution declaring 2016 as the Year of Remembrance for Victims of Pacification of the "Wujek" mine. Currently anniversary celebrations are beginning to take a national dimension, and were efficiently incorporated into the narrative condemning the imposition of martial law and its consequences for Poland.

\section{LOCAL DIMENSION OF RITUALIZATION OF HOLIDAY CELEBRATIONS}

In the Polish tradition of observance of public holidays and anniversaries, mechanisms involving their ritualization are perfectly visible. According to Jean Duvignaud (2011), ritualization involves reconstruction of the past in the present. Shaping of symbolic space through commemoration of historical events turns the latter into artifacts embedded in the currently lived reality. In practice, in the process of ritualization past events start to be experienced individually, and the emotions thus invoked in participants of the ritual significantly strengthen its social impact. As a result, in the opinion of Jonathan H. Turner (2007), within a specific group personal emotions take on a group character, which connects the members of the group, evokes a sense of community and creates symbols understood by all. Thus rousing a specific emotional response involves the receiver in the narrative act, making the communicated message easier to accept. Each subsequent reproduction of the ritual will invoke a similar reaction, activated through appropriate mechanisms of memory.

Particular conditions of the communication act, taking place according to a specific scenario governing the celebration of holidays and anniversaries, mean that it can be considered as a process invoking among participants of the ritual a sense of belonging to the community, leading to the formation of the state of communitas. Communitas is an effect caused by a group of people being together in time and space - without meeting this condition there is no possibility of forming a real community, as every community is the outcome of a specific contextual situation in which a feedback loop leads to strong identification of individuals with the group and the catalog of values it adheres to. That effect is what the ruling elites want to achieve in the course of implementation of politics of history (Turner, 2010).

The above interdependencies are quite capably used in the process of shaping the state symbolic space at the central level. Politicians increasingly well under- 
stand the significance of public holidays and anniversaries in building a relevant national narrative. From year to year, the celebrations are prepared with greater meticulousness, even more effectively influencing the attitudes and way of thinking of their intended audience. Local elites do not yet fully appreciate the role of festivals and historical anniversaries in politics, and still do not see the opportunities offered by their appropriate use in building political capital. Creation of historical narratives is thus left to the state authorities based in Warsaw, while the regional and local elites see their role differently. Watching various holiday celebration in the regions, it is difficult to discern any specific characteristics significantly distinguishing them from nationwide celebrations. Instead, we can clearly identify repetitive elements present in all celebrations across the country. One of the most important elements is the meeting of the authorities with the public. At local level, it takes place in most Polish cities, independently of their size. Of course - as mentioned - during pre-election periods participation of local politicians in all festivities intensifies. All such “meetings” are made up of a number of permanent components - after all, according to the rules of rite creation, repetition and predictability are its immanent characteristics. An important element is the speech by the representatives of the authorities, linking the past events in some way with the present. Other constants are also the laying of flowers, paying homage to national symbols, parades, marches, etc. All these elements affect the sense of community and strengthen group ties. With a high degree of probability we can state that local Polish politicians - similarly to their counterparts in other countries - will most likely be forced to redefine their roles in the region or locality, which in turn means turning their eye to other planes of activity - including that of politics of history.

\section{CONCLUSIONS}

Celebrations of anniversaries of historical events and national holidays are a perfect tool for communication with the public and a mechanism for shaping the state symbolic space. At a local level, however, they are used to a limited and insufficient degree. This is due to at least several reasons.

The first is the dominance of centrally organized celebrations in the capital across two dimensions:

a) Media dimension: Festivities held in Warsaw attract media attention and are broadcast, commented on and interpreted in various media, mainly due to participation therein of representatives of the highest state authorities, who use them as an opportunity to accumulate political capital. 
b) The second dimension is the ceremonial aspect: The centrally defined scenario of celebrations is copied by local authorities, which only very rarely decide to introduce regional elements to this pre-defined agenda.

Another reason for insufficient use of opportunity offered by public holidays and anniversaries as a political tool is the low impact of this type of activity on the election result. Of course, in the campaigning period various events attract local politicians, as this is an excellent opportunity to present oneself and enter into direct contact with voters. But voters themselves expect the local politicians rather to address current, most pressing needs of the local community, such as construction and repair of roads, efficient delivery of basic services, ensuring enough places for children in nurseries and kindergartens, etc. Politics of history rate much lower on the priority list, what is clearly reflected in political programs of political groupings at both local and state-wide level. Even if voters are aware of a need for proper organization of symbolic space of their city, they rarely articulate this desire during the election campaign. Initiatives pushing for erection of a monument or organization of anniversary celebrations are more likely to emerge outside the electoral season, and be communicated to the current rulers in a region.

Finally, marginal use of holidays and anniversaries as political tool at the local level is also due to lack of ideas on how to approach organization of these celebrations. Simply copying the scenario of festivities from the capital does not bring the expected effect; moreover, it is difficult to even try to match the scale of Warsaw celebrations in the regions. Truthfully, the local governments of various level in Poland also proved incapable of turning celebrations of patriotic anniversaries into family-friendly events of a picnic-like variety (what has been perfected by the Americans). Consequently, local communities are disinterested in these celebrations, which in turn discourages the authorities from undertaking similar initiatives in the future. Local governments have shown themselves much more suited to organization of events such as harvest festivals rather than public holidays and significant anniversaries.

This does not mean, however, that local authorities totally gave up on attempts to shape the symbolic space in their respective region or locality. On the contrary, remembrance is one of the main foci of political activity of the ruling elite at this level. However, in this case tools other than celebration of anniversaries and holidays are considered to be much more effective. Such celebrations are treated more as just another obligation to fulfill at the local level - their potential is so far much better understood and made use of in building national historical narratives by the central state authorities. 


\section{Legal acts:}

Act of 15 February 1989 on the establishment of the National Day of Independence. Journal of Laws 1989 No. 6, item 34.

Act of 17 May 1989 on relations between the State and the Catholic Church in the Polish People’s Republic. Journal of Laws 1989 No. 29, item 154.

Act of 6 April 1990 (a) re-establishing the National Day of May 3rd. Journal of Laws 1990 No. 28, item 160.

Act of 6 April 1990 (b) abolishing July 22nd as the National Day of Poland's Revival. Journal of Laws 1990 No. 28, item 159.

Act of 30 July 1992 establishing the Day of the Polish Army. Journal of Laws 1992 No. 60 , item 303.

Act of 27 July 2005 establishing 31st August as the Day of Solidarity and Freedom. Journal of Laws 2005 No. 155, item 1295.

Act of 9 October 2009 establishing the National Day of Remembrance of the Warsaw Uprising. Journal of Laws 2009 No. 206, item 1588.

Act of 24 September 2010 amending the Law - the Labour Code and some other laws. Journal of Laws 2010 No. 224, item 1459.

Act of 16 December 2010 amending the Act on employment promotion and labour market institutions and some other acts. Journal of Laws 2010 No. 257, item 1725.

Act of 3 February 2011 establishing the Doomed Soldiers Memorial Day. Journal of Laws 2011 No. 32, item 160.

Act of 24 April 2015 establishing the National Day of Victory. Journal of Laws 2015, item 622.

Proclamation of the Marshal of the Polish Sejm of 19 December 2014 on the uniform text of the Act on days off from work. Journal of Laws 2015, item 90.

Regulation by the President of the Republic of Poland dated August 22, 2003 on recognition as a Polish history memorial site. Journal of Laws 2003 No. 148, item 1448.

Resolution of the Sejm of the Republic of Poland of June 21, 2006 establishing June 28 as the National Day of Remembrance of Poznań June 1956 Events. Parliamentary Journal 2006 No. 43, item 455.

\section{References:}

Cassirer, E. (1971). Esej o człowieku: wstęp do filozofii i kultury. Warszawa: Czytelnik.

Czubiński, A. (1988). Powstanie wielkopolskie 1918-1919: geneza - charakter - znaczenie. Poznań: Wydawnictwo Poznańskie.

Dąbrowski, M. (2000). Lubelski lipiec 1980. Lublin: Zarząd Regionu Środkowowschodniego NSZZ Solidarność.

Dudek, A. (2003). Stan wojenny w Polsce 1981-1983. Warszawa: Instytut Pamięci Narodowej.

Duvignaud, J. (2011). Dar z niczego. O antropologii święta. Warszawa: Wydawnictwa Uniwersytetu Warszawskiego.

Eisler, J. (2006). Polski rok 1968. Warszawa: Instytut Pamięci Narodowej. 
Grzelczak, P. (2016). Poznański Czerwiec 1956. Walka o pamięć w latach 1956-1989. Poznań: Wydawnictwo Nauka i Innowacje, Instytut Pamięci Narodowej.

Kącka, K. (2013). Upamiętnianie jako zadanie i wyzwanie władz administracyjnych. Sprawa pomnika wdzięczności Armii Czerwonej w Toruniu. In: D. Plecka (ed.), Współczesne wyzwania administracji rzqdowej i samorzqdowej (p. 305-323). Toruń: Wydawnictwo Adam Marszałek.

Kącka, K. (2014). Lokalny wymiar polityki historycznej. Studium przypadku: Toruń. In: D. Plecka (ed.), Administracja publiczna w projektach politycznych (p. 281-297). Toruń: Wydawnictwo Adam Marszałek.

Kącka, K. (2015a). Holidays and Celebrations as an Element Organizing the State Symbolic Space - the Case of Poland in the 20th and 21st Centuries. Kultura i Edukacja, 4 (110), 66-84. DOI: 10.15804/kie.2015.04.04.

Kącka, K. (2015b). Polityka historyczna: kreatorzy, narzędzia, mechanizmy działania przykład Polski. In: K. Kącka, J. Piechowiak-Lamparska, A. Ratke-Majewska (eds.), Narracje pamięci: między politykq a historiq (p. 59-80). Toruń: Wydawnictwo Naukowe UMK.

Kąkolewski, I. (2015). Krzyżacy. Przeklęci bohaterowie. In: R. Traba, H.H. Hahn (eds.), Polsko-niemieckie miejsca pamięci. Vol. 2: Wspólne/Oddzielne (p. 225-248). Warszawa: Wydawnictwo Naukowe: Scholar.

Kosthorst, E. (1985). Geschichtsbewusstsein. Überlegungen zur zentralen Kategorie eines neuen Ansatzes der Geschichtsdidaktik. In: H. Süßmuth (ed.), Geschichtsdidaktische Positionen. Bestandsaufnahme und Neuorientierung (p. 199-222). Paderborn: Verlag. Kubisz, B. (2008). Wojsko Polskie - II wojna światowa. No. 9: Westerplatte 1939. Warszawa: Hachete Livre Polska.

Kurczewski, J. (ed.) (2003). Lokalne społeczności obywatelskie. Warszawa: Uniwersytet Warszawski, Instytut Stosowanych Nauk Społecznych, Ośrodek Badań Społecznych. Madajczyk, P. (2012). Cień roku '68. Warszawa: Instytut Studiów Politycznych Polskiej Akademii Nauk.

Ociepka, B. (2001). Polska-Niemcy. Narzędzia miękkiej siły w polityce zagranicznej. Przegląd Zachodni, 67 (2), 48-49.

Piechowiak-Lamparska, J. (2014). Dependence Path in the Process of Achieving Transitional Justice on the Post-Soviet Area. Comparative Studies on the Transition in Estonia, Georgia, and Poland. Athenaeum. Polskie Studia Politologiczne, 44, 164-176. DOI: 10.15804/athena.2014.44.10.

Przecławski, K. (2001). Człowiek a turystyka. Zarys socjologii turystyki. Kraków: Albis. Raina, P., Szostak, W. (2003). Operacja „Lato-80”. Pelplin: Bernardinum.

Sasanka, P. (2006). Czerwiec 1976. Geneza-przebieg-konsekwencje. Warszawa: Instytut Pamięci Narodowej.

Schenk, F.B. (2009). Tannenberg/Grunwald. In: E. François, H. Schulze (eds.), Deutsche Erinnerungsorte. Vol. 1 (p. 438-454). München: Verlag C.H. Beck.

Szpociński, A. (1983). Kanon historyczny. Studia Socjologiczne, 4 (91), 129-146.

Turner, J.H. (2007). Human Emotions: A Sociological Theory. London-New York: Routledge. 
Turner, V. (2010). Proces rytualny. Struktura i antystruktura. Warszawa: Państwowy Instytut Wydawniczy.

Urbańczyk, P. (2008). Trudne poczq̨tki Polski. Wrocław: Fundacja na Rzecz Nauki Polskiej.

Walzer, M. (2006). Polityka i namiętność. O bardziej egalitarny liberalizm. Warszawa: Warszawskie Wydawnictwo Literackie Muza.

Wolff-Powęska, A. (2007). Polskie spory o historię i pamięć: polityka historyczna. Przegląd Zachodni, 63 (1), 3-44.

Wolff-Powęska, A. (2011). Pamięć - brzemię i uwolnienie. Niemcy wobec nazistowskiej przeszłości (1945-2010). Poznań: Zysk i s-ka.

Zaborski, M. (2011). Współczesne pomniki i miejsca pamięci w polskiej i niemieckiej kulturze politycznej. Toruń: Wydawnictwo Adam Marszałek. 